\title{
Influence of Literature-In-English and Choice of School on Senior Secondary Students' Achievement in English Language
}

\author{
Olayinka.M. Iyekekpolor* \\ Department of Arts Education, University of Nigeria, Nsukka, Nigeria \\ Josephine,U. Akabogu \\ Department of Arts Education, University of Nigeria, Nsukka, Nigeria \\ Cajetan I. Egbe \\ Department of Arts Education, University of Nigeria, Nsukka, Nigeria
}

\begin{abstract}
The study focused on the influence literature in English and choice of school portend on senior secondary students' achievement in English language. The work covered a period of six years 2012-2017 and adopted an ex-post facto research design. WAEC and NECO results of 1,940 students from the two schools whose results were released by the examining bodies for the period under investigation, were used to collect data. Two research questions were answered using Mean and Standard deviation while research hypotheses were tested using t-test statistic at 0.05 level of significance. The study recommended among other issues that literature-in-English be integrated into SSS curriculum across board.
\end{abstract}

Keywords: Federal, State, rural, urban, WAEC, NECO

DOI: $10.7176 / J L L L / 77-02$

Publication date:March $31^{\text {st }} 2021$

\section{INTRODUCTION}

The English language is a language of globalization and trade. Due to the role the language plays in the nation's unity and development in all spheres of human endeavors, efforts at ensuring functional acquisition of the language, is worthwhile. According to the National Policy on Education (2013), the English language is a subject at the primary school level. It is used as a medium of instruction from the fourth year in the primary school and one of the core subjects at the basic and senior secondary levels. It is a subject in which candidates must pass at credit level in order to gain admission into higher institutions of learning (Eze, 2011, Adepoju \& Oluchukwu, 2011). Students who wish to study outside the shores of Nigeria are mandated to have a minimum of IELTS 6 or its equivalent SSCE (WAEC) (credit 6) or above (The University of Sheffield, 2018).

Consequently, Parents and guardians make a particular choice of secondary schools that they want for their children irrespective of cost and location with the singular goal of wanting them to achieve success in the senior secondary certificate examination (SSCE) Adepoju \& Oluchukwu, 2011. This belief implies that the type of school a student attends contributes to his/her achievement in the English language. Alimi, Ehinola \& Alabi (2012) submit that most of the students who secure admission into the universities and institutions of higher learning are from private schools.

The goal of English language teaching today has moved from the attainment of linguistic competence where a learner is expected to be aware of the norms of the language. It is presently that of attaining communicative competence. Larsen-Freeman \& Anderson (2016) submitted that learning of the English language would achieve intercultural communicative competence. In the opinion of Profesorado (2010), literature can introduce students to a range of aspects of both the English language and the English culture. The writing further stressed that works of Shakespeare, for instance, encapsulates elements of the English culture. It can, therefore, be said that learning the English language is learning the culture of the native speakers and be able to interact successfully internationally. Literature in English has been regarded as a medium of propagating cultural values and ideas Adejimola and Ojuolape 2013 \& Mohammed, 2013. In the view of Labo-Popoola (2010), Literature in English is the foundation for language learning through which different cultures could be identified. The position of Ghon (2002), Shrestha, (2008), Khatib et al. (2011), and Mohammed (2013) is that literature assists in the development of language skills and supports the acquisition of the target language in a bid to make the users competent. Literature is a tool for the transmission of culture from one generation to another and a medium through which the tradition of a culture could be discovered (Murat, 2005) says; this view is still being held today. In as much as language and culture are synonymous, then the teaching of literature can be said to have a beneficial impact on the teaching and learning of the English language.

Twenty-five years ago, Taraba state was listed among the educationally disadvantaged States in Nigeria Muscari (2016); BenTenBlog (2016). The rationale behind this step was the goal of ensuring a uniform development of the educational sector by granting some preference to candidates from the state during the process 
of admission into universities. This step nevertheless did not rub off the essentiality of obtaining a credit pass in English language as a prerequisite for admission. It would be necessary therefore to find out how students in the state faired in the English language and if they are found out to be performing below credit level, it will be necessary to proffer solutions that will assist the students in becoming competent in the language.

Adesulu (2015) bewailed the mass failure of candidates in May/June WAEC examination, where only 39\% of the candidates had credit pass in the English language. Performance of students in WAEC has not been anything to rejoice over in the past years as lamented by Eguridi (Head of WAEC office in Nigeria) who gave statistics as follows: 2013 credit pass in English language as 38.30\%; in 2014 credit pass was $31.28 \%$. The reality, therefore, dawns on all stakeholders that any effort at facilitating an improvement in students' achievement in the English language is worthwhile.

B. F. Skinner on Behaviourist theory posits that language acquisition is a stimulus-response process and the result of nurture. The Mentalist theory by Noam Chomsky is of the view that language acquisition is by application and that the role of exposure of learners to the target language is vital. In contrast, the Interactionist theory believes that the acquisition of language is a process of nature and nurture, analogy and application with practice and exposure (Oyetunde, 2013). A closer look at the propositions of the three theories of language stated above implies that learners need to 'dwell' in the English language in order to acquire the language or develop competence. Literature in English, therefore, seems to be able to create the world in which readers live and in the mind's eye travel to other countries apart from the one he/she resides and then is able to learn the culture of the people been read about.

This study attempts to look into the achievement of students in the English language at the SSCE level from 2012 to 2017. It also aims at finding out how students faired, possible factors responsible for their achievement, and probable ways of encouraging higher achievement in the subject through the teaching of literature in English. This will help students from secondary schools in Taraba state to become high fliers and possibly have the name of the state deleted from the list of educationally disadvantaged states in Nigeria.

\section{LITERATURE REVIEW}

Poor achievement of students over the years in English language senior secondary certificate examination (SSCE) provoked scholars to continue to search for ways by which performance in the subject can be improved upon. Mohammed (2011) observes that researches have been on to explore the best practice to employ in the art of achieving this goal.

Chan (1999) in the study titled: literature, language awareness, and EFL, recommends that literature should be taught since it uses powerful language and contains the skill needed for language learning. A study titled: the effect of school type on academic achievement: evidence from Indonesia; carried out by Newhouse \& Beegle (2005); revealed that the higher quality input at public junior secondary school led to high test scores thereby making the performance at the public school better than that of the Muslim and non-Muslim private schools. The study presents public schools to be more effective than private schools at imparting cognitive skills. However, in Nigeria, the opposite is the case due to a lack of proper monitoring and supervision. Private schools are believed to be better in terms of human resources, infrastructure, and instructional materials, consequently achieving better results than public schools in Nigeria. Unfortunately, the public schools have more experienced teachers who are left to do whatever they like with the teaching; this view can be researched upon. In a study titled: the relationship between school facilities and academic achievement, by Doarne (2008), it was observed that school environment and facility contribute to effectiveness in teaching and learning. The opinion of Yusuf \& Adigun (2010) was that parents enroll their wards and children in rural schools for senior school certificate examination because of the feeling that the performance of students in the urban schools was poor. Nevertheless, a study titled: influence of school sex, location, and type on students' academic performance; was explored by Yusuf \& Adigun (2010) and revealed that these factors had no significant influence on students' performance rather stakeholders should encourage students to sit up in order to bring about an improvement in their academics.

A school, however, is not complete without the teachers who coordinate the teaching and learning process. Omotere (2011), Agharuwhe (2013), and Prasetio (2017) believed that the competency of teachers does influence students' achievement partially but not significantly. Prasetio (2017) is rather of the opinion that facilities of the school, and other factors such as peer group, parents' socioeconomic factors among others, influence students' achievement. This study, however, will verify this stand since the quality of teachers in a school can further influence the decision of parents with respect to the choice of school for their wards.

Eze (2011) carried out a study on the influence of literature in English, gender, and environment on senior secondary school students' achievement in the English language in Nsukka local government area of Enugu state. Among other things, the study posits that literature in English contributes positively to students' achievement in the English language, and as a result, teachers of the English language should integrate literature in English while teaching the former. The study further suggested that all students be made to offer the subject. As part of efforts made by researchers at facilitating proficiency of learners in the English language, 
In the work of Adepoju \& Oluchukwu (2011), it was observed that students, in urban areas, perform better significantly than students in the rural areas in English language and that there is the challenge of a dearth of equal educational opportunities in Nigeria. This stand runs contrary to the position of parents who prefer to register their children for SSCE examination in the rural areas as postulated earlier by Yusuf \& Adigun, (2010).

Alimi, Ehinola \& Alabi (2012) embarked on a study on school types, facilities, and academic performance of students in senior secondary schools in Ondo State, Nigeria. As revealed by the study, public schools need more facilities as there was a significant difference in the facilities available in public and private schools in Ondo state to the favor of private schools. This accounts for the reason why irrespective of cost or distance, parents and guardians prefer to enroll their wards in schools that are well developed, and they feel students will obtain the needed prerequisite to move to the tertiary level.

In 2013, Mohammed conducted a research titled: the effect of teaching literature on learning English language: a study on EFS (English as a Foreign Students) and EFL classes. The study presented literature as the source of inspiration and expression of social, philosophical, theological ideas of a group of people and that literature is a powerful tool for presentation of the history of a community.

A study was carried out by Adejimola \& Ojuolape (2013) on the relationship between the English language and literature-in-English in secondary schools. The work posits that literature in English can be a tool for enhancing students' performance in the English language.

El-Omari (2016) believes that factors such as attitude, social, socioeconomic, and extracurricular issues influence students' achievement in the English language in the study carried out on factors affecting students' performance in English language learning.

Recently, Paran (2017) made revelations on the importance of literature in English to English language acquisition in the study titled: the effectiveness of literature on acquisition of language skills and intercultural understanding in the high school context. Through the study, it was observed that literature contributes to the learning of the English language in the areas of vocabulary and reading skill development.

Evidences emanating from previous researches have supported the fact that literature in English boosts students' achievement in the English language. This present study will want to find out if this is a reality in secondary schools in Taraba state. Researches have revealed that the type of school a student attends contribute to the ultimate achievement of such student in English language at the SSCE level. This study will furthermore want to find out if the type of school or choice of school affects students' achievement in the English language in Taraba state. The study will also explore the reality of the theories of language acquisition on students' achievement in the English language in the state.

\subsection{The genres of literature and acquisition of English language skills}

Literature has been defined in various ways by various authors. The Oxford Concise English Dictionary defines literature as 'written works, especially those whose value lies in beauty of language or in emotional effect'. Literature has further been described as an expression of the cultural experience of a people of which language is a part Adejimola \& Ojuolape (2013). It, therefore, presupposes that if effort is made at learning the language of a group of people, the knowledge of literature of the people is indispensable. Language expresses the literature of a group of people. Therefore, language is a tool through which literature exists; literature likewise is a tool through which language is propagated. A close look at the specific areas where literature meets with the teaching of the English language is an essentiality. Literature is divided into three classes, which are technically called genre. They are; drama, prose, and poetry. The teaching of literature is activity-oriented (Adejimola \& Ojuolape,2013)

\section{OBJECTIVES OF THE STUDY}

Specifically, this study set out to:

1. Discover the influence literature-in English has on senior secondary students' achievement in English language. 2. Determine the impact of school type on students' achievement in the English language.

Significance of the study

\section{SIGNIFICANCE OF THE STUDY}

It is hoped that the study will awaken reading culture in students as Calia (2009) is of the view that the ability to read in a target language is the easiest way to learn that language. Possibly, it will provoke the review of the present senior secondary curriculum to accommodate literature in English as one of the core compulsory subjects for all students. The study is also expected to benefit proprietors and stakeholders in secondary school education as it may motivate them to provide varied literary texts for students at various levels. In this way, economic factors will not be a hindrance to the goal of achieving competence in the English language. Parents hopefully will benefit from the study as it could be a guide for them in the choice of schools for their wards/children. The body responsible for the monitoring of education at the federal and state levels will, through this study, be expected to be awake to fulfill the purpose of their establishment. One of the goals of the general philosophy of the National 
Policy of Education (NPE) (2013) is equitable access to educational opportunities for all Nigerians irrespective of where their place of origin or residence. Through this research, it is hoped that the government will put mechanisms in place to ensure an equal spread of educational opportunities and facilities for all its citizens. The study will further give room to further inquiry such as the role supervision and monitoring play in English language learning, the influence of gender on students' achievement in the English language, and the influence of the boarding system on students' achievement in the English language.

\section{RESEARCH QUESTIONS}

The following research questions were raised to pilot the study:

1. To what extent does literature in English influence students' mean achievement scores in the English language?

2. In what way does the choice of school influence students' mean achievement scores in the English language?

\section{HYPOTHESES}

Two null hypotheses were formulated and tested in this study.

HO1: There is no significant difference in the mean achievement scores of students who offer literature in English and mean achievement scores of students who do not offer literature in English at the senior secondary school level.

H02: There is no significant difference in the mean achievement scores of students who attend Federal government-owned secondary schools, and the mean achievement scores students who attend state-owned secondary schools in the English language.

\section{METHODOLOGY}

The study adopted an ex-post-facto research design. Nworgu (2006) describes this type of design as the one that is similar to the experimental study in the sense that it also seeks to establish cause-effect relationships. However, it differs in that the researcher usually has no control over the variables of interest and therefore cannot manipulate them. Indeed, the researcher only attempts to link some already existing effects or observation to some variables as causative agents. Nworgu (2006) maintained that at the commencement of the study, the researcher finds that the subjects are already assigned to or classified into various levels of the variables whose effects are being investigated, and he/she cannot alter this. This design is appropriate because the researcher did not manipulate independent variables. Instead, the effects of the independent variables on the dependent variable were determined.

The study was conducted in Taraba state, Nigeria. Two co-educational senior secondary schools were purposely selected for the study. One of the schools was a Federal government-owned school, and the other was a State government-owned school. Existing results of the students from WAEC and NECO from 2012-2013 were used as instrument for data collection. A total of 1,940 students whose results were released by the examining bodies within the period under investigation were used for the study. WAEC AND NECO examinations and results are standardized tests that do not need further validation; hence the results were reliable for data collection. The results from the schools were grouped into two; Group 1 consists of students who take literature in English, and Group 2 consists of students who do not take literature in English. The research questions were answered using mean and standard deviation, while the t-test statistic was used to test the null hypothesis at 0.05 level of significance.

\section{RESULTS}

The research questions for the study were examined, and the hypotheses formulated were answered. Below are the details of the results:

Research Question One: To what extent does literature in English influence students' achievement in English Language? 
Table 1: Mean and Standard Deviation of the extent to which Literature in English Influence Students' Achievement in English Language

\begin{tabular}{|l|l|l|l|l|}
\hline S/N & \multicolumn{1}{|c|}{ Year } & \multicolumn{1}{|c|}{ Groups } & \multicolumn{1}{|c|}{ SD } \\
\hline 1 & 2012 & With Literature & 40.62 & 12.68 \\
& & Without Literature & 47.30 & 11.24 \\
\hline 2 & 2013 & With Literature & 39.77 & 13.76 \\
& & Without Literature & 35.79 & 15.25 \\
\hline 3 & 2014 & With Literature & 42.27 & 14.52 \\
& & Without Literature & 37.95 & 16.47 \\
\hline 4 & 2015 & With Literature & 49.12 & 9.87 \\
& & Without Literature & 50.42 & 10.73 \\
\hline 5 & 2016 & With Literature & 58.47 & 6.09 \\
& & Without Literature & 59.14 & 6.44 \\
\hline 6 & 2017 & With Literature & 58.95 & 6.40 \\
& & Without Literature & 60.82 & 5.99 \\
\hline & Cluster Mean & With Literature & $\mathbf{4 9 . 7 6}$ & $\mathbf{1 3 . 5 1}$ \\
& & Without Literature & $\mathbf{4 8 . 1 1}$ & $\mathbf{1 5 . 6 8}$ \\
\hline
\end{tabular}

The results of the study, as presented in Table 1, show the mean scores and standard deviation of respondents on the extent literature in English influence students' achievement in English Language. The result of the study showed that in the year 2012, students who took literature had a mean of 40.62, while those who did not take literature had a mean score of 47.30. In 2013, students who took literature had a mean score of 39.77, while those who did not take literature had a mean score of 35.79. In 2014, students who took literature had a mean of 42.27 , while those who did not take literature had a mean score of 37.95. In 2015 students who took literature had a mean of 49.12, while those who did not take literature had a mean score of 50.42. In 2016 students who take literature had a mean of 58.47, while those who did not take literature had a mean score of 59.14, and in 2017 students who took literature had a mean of 58.95, while those who did not offer literature had a mean score of 60.82 . The overall mean of 49.76 was obtained for students who took literature, while a mean of 48.11 was obtained for students who did not take literature. The result of this study shows that the mean score of students who took literature in English from 2012-2017 was higher than the mean score of students who did not take literature in English within the same period. This implies that literature in English may have some positive influence on students' achievement in the English language.

Research Question Two: To what extent does the choice of school influence students' mean achievement scores in the English language?

Table 2: Mean and Standard Deviation of the extent to which choice of school influence students' mean achievement scores in English language

\begin{tabular}{|l|l|l|l|l|}
\hline $\mathbf{S} / \mathbf{N}$ & \multicolumn{1}{|c|}{ Year } & \multicolumn{1}{c|}{ Ownership } & \multicolumn{1}{c|}{ SD } \\
\hline 1 & 2013 & State & 23.05 & 9.12 \\
& & Federal & 43.80 & 12.17 \\
\hline 2 & 2014 & State & 22.37 & 8.40 \\
& & Federal & 48.78 & 10.45 \\
\hline 3 & 2015 & State & 48.81 & 11.18 \\
& & Federal & 51.59 & 9.41 \\
\hline 4 & 2016 & State & 54.99 & 6.07 \\
& & Federal & 60.79 & 5.45 \\
\hline 5 & 2017 & State & 61.86 & 7.07 \\
& & Federal & 57.94 & 4.11 \\
\hline & Cluster Mean & State & $\mathbf{4 4 . 5 3}$ & $\mathbf{1 8 . 3 9}$ \\
& & Federal & $\mathbf{5 1 . 1 8}$ & $\mathbf{1 1 . 8 1}$ \\
\hline
\end{tabular}

The results of the study, as presented in Table 2, show the mean scores and standard deviation of respondents on the extent to which choice of school influence students' mean achievement scores in the English language. The result of the study showed that in the year 2013, students who attended state schools had a mean score of 23.05 , while students that attended federal schools had a mean score of 43.80. In 2014, students who attended state schools had a mean score of 22.37, while students that attended federal schools had a mean score of 48.78. In 2015, students who attended state schools had a mean score of 48.81, while students that attended federal schools had a mean score of 51.59. In 2016, students who attended state schools had a mean score of 54.99, while students that attended federal schools had a mean score of 60.79 and in 2017, students who attended state schools had a mean score of 61.86, while students that attended federal schools had a mean score of 57.94. The total mean score of 44.53 was obtained for students who attended state schools between 2013-2017 while a mean score of 51.18 was obtained 
for students who attended federal schools from 2013-2017. The result of the study shows that students who attended federal schools had higher mean scores than those who attended a state school.

Hypothesis One: There is no significant difference in the mean achievement scores of students who offer literature in English and students who do not take literature in English in the English language at the senior secondary level. Table 3: T-test analysis of the significant difference in the mean achievement scores of students who took literature in English and students who did not take literature in English in the English language.

\begin{tabular}{|l|l|l|l|l|l|l|l|c|}
\hline & Group & $\mathrm{N}$ & $\bar{X}$ & $\mathrm{SD}$ & $\mathrm{t}$-cal & Df & Sig & Dec \\
\hline & With Literature & 714 & 49.76 & 13.51 & 2.34 & 1938 & \multirow{2}{*}{0.02} & $\mathrm{~S}$ \\
& Without Literature & 1226 & 48.11 & 15.68 & & & & \\
\hline
\end{tabular}

The result of the study, as presented in Table 3, shows the t-test analysis of the significant difference in the mean achievement scores of students who took literature in English and students who did not take literature in English in the English language at the senior secondary level. The result shows that a t-value of 2.34 with a degree of freedom of 1938 and a significant value of 0.02 were obtained. Since the significant value of 0.02 is less than 0.05 set as a level of significance, this means the result is significant. The null hypothesis, which stated that there is no significant difference in the mean achievement scores of students who took literature in English and students who did not take literature in English in the English language at the senior secondary level, is therefore rejected. The inference, therefore, is that there was a significant difference in the mean achievement scores of students who took literature in English and mean achievement scores of students who did not take literature in English in the English language at the senior secondary level.

Hypothesis Two: There was no significant difference in the mean achievement scores of students who attended Federal government-owned school and State government-owned school in English language

Table 4: t-test analysis of the significant difference in the mean achievement scores of students who attended the Federal government-owned school and the state government-owned school in the English language.

\begin{tabular}{|l|l|l|l|l|l|l|l|c|}
\hline $\mathrm{S} / \mathrm{N}$ & Ownership & $\mathrm{N}$ & $\bar{X}$ & $\mathrm{SD}$ & t-cal & Df & Sig & Dec \\
\hline & State & 717 & 44.53 & 18.39 & -9.67 & 1938 & \multirow{2}{*}{0.00} & \multirow{2}{*}{$\mathrm{S}$} \\
& Federal & 1223 & 51.18 & 11.81 & & & \\
\hline
\end{tabular}

The result of the study, as presented in Table 4, shows the t-test analysis of the significant difference in the mean achievement scores of students who attended Federal government-owned schools and state governmentowned schools in the English language. The result shows that a t-value of -9.67 with a degree of freedom of 1938 and a significant value of 0.00 was obtained. Since the significant value of 0.00 is less than 0.05 set as a level of significance, this means the result is significant. The null hypothesis, which stated that there is no significant difference in the mean achievement scores of students who attended Federal government-owned schools and state government-owned schools in the English language, is therefore rejected. The inference, therefore, is that there was a significant difference in the mean achievement scores of students who attended Federal Government-owned schools and mean achievement scores of students who attended state government-owned schools in the English Language.

\section{DISCUSSION}

The study showed that students who took literature in English had a higher mean score than the mean score of students who did not take literature in English in the English language. The findings also revealed a significant difference in the mean achievement scores of students who offer literature in English and the mean achievement scores of students who do not offer literature in English in the English language at the senior secondary level. This is in agreement with Eze (2011), Adejimola \& Ojuolape (2013), Mohammed (2013), El-Omari (2016), and the work of Paran (2017) who believed that the study of literature would help to improve the learning of language skills. The study furthermore revealed that non-literature students could perform well in the English language, as revealed in the mean score presented in Table 1 for the years 2016 and 2017. Non-literature students had a mean score of 59.147, while literature in English students had a mean score of 58.478 in 2016 and a mean score of 60.078 and 58.957 respectively in 2017. This implies that, if non-literature students could achieve this feat, they would become high fliers in English language achievement, if they have the opportunity to take literature. This further supports the opinion of Eze (2011), that all students be given the opportunity to take literature in English.

The results of the study, as revealed by Tables 3 and 4, show that the type of school students attend affects their achievement in the English language, particularly in Nigeria. This is in disagreement with the views of Yusuf \& Adigun (2010) and Alimi, Ehinola \& Alabi (2012), who were of the opinion that school type had no impact on students' achievement. As revealed by this study, students in the federal government-owned school had a mean score of 51.180 as against the mean score of 44.538 obtained by students from the state school in the English language with a significant value of 0.00 less than 0.05 . However, the study ran contrary to the work of Newhouse \& Beegle (2005), where government-owned schools performed better than other schools in Indonesia. The factor responsible for this disagreement could be that there is no equality in the facilities available in both Federal owned and state-owned secondary schools as an observation made by Doarne (2008) and Alimi, Ehinola \& Alabi (2012) 
supports the fact that facilities available in schools has a way of boosting students' achievement in academics. The Federal schools may be better supervised than the state-owned schools, the work of Adepoju \& Oluchukwu (2011) attest to the fact that lack of supervision, monitoring and evaluation machinery are factors that contribute to the poor performance of students in secondary schools. It is also possible that the competence of English language teachers in Federal government-owned schools is higher than the competence of English language teachers at the state-owned schools Ugbe \& Agim (2009) and Omotere (2011) were of this opinion. However, Agharuwhe (2013) and Prasetio (2017) were of the view that teachers' competence influences secondary school students' achievement but not significantly. Lack of proper coverage of the examination syllabus can also be a factor responsible for the significant differences between the two groups of schools. However, these speculations are subject to further researches as many factors can influence academic achievement, as observed by Doarne (2008). Nevertheless, this disparity goes contrary to the broad goal of the National Policy of Education that says equal educational opportunities be made available to all Nigerian children.

\section{RECOMMENDATIONS}

In light of the findings above, the following recommendations were made.

It is recommended that teachers of the English language should incorporate literature into their teaching so that students can have a broad basis for interaction in the target language since the acquisition of language is based on analogy, application, practice, exposure, nature and nurture. Curriculum planners and stakeholders should give opportunities to all students at the senior secondary level to offer literature in English as it will expose them more to the culture of the native speakers of the language. The government both at the federal and state levels should ensure that equal learning facilities are made available for all secondary schools in the country, so as to give room for equal educational opportunities to all Nigerian citizens at the senior secondary level. Supervision and monitoring of schools at the state level should be a priority, the state ministry of education can collaborate with the federal arm of in school evaluators to ensure the right knowledge is passed across to the students. School administrators should provide proper coverage of the examination syllabus for all students in the English language to ensure high achievement in the subject.

\section{CONCLUSION}

This study has attempted to find out the influence of literature in English on students' achievement in the English language. It is also possible to carry out similar studies in relation to science subjects as it was discovered that nonliterature students performed better at some point than the literature students, though the difference was not significant. The study has not focused on parameters such as gender, location, boarding or day facilities. There were cases of results that were withheld, particularly by the WAEC due to examination malpractice or undisclosed factor. Unfortunately, though the researcher endeavored to check this, there was a repetition of certain names on the computer sheets presented by WAEC to one of the schools; this may bring in human error. In the long run, the study was able to achieve its goals and objectives.

\section{References}

Adepoju, T. L. \& Oluckukwu, E. E. (2011) A study Secondary School Students' Academic Performance at the Senior School Certificate Examinations and implications for educational Planning and Policy in Nigeria African Research Review An International Multidisciplinary Journal , Ethiopia vol 5(6) serial number 23 Pp 314-333 retrieved online from DOI:http://dx.doi.org/10.4314/afrrev.v5i6.26 on 21/3/18

Adesulu, D. (2015) WAEC releases results with 39\% pass in eng/maths A publication of Vanguard newspaper dated 10th August,2015 retrieved from https://www.vanguardngr.com on 23/3/18

Alimi, O. S. Ehinola,G.B \& Alabi,F.O (2012) School types, facilities and academic performance of students in senior secondary schools in Ondo State, Nigeria. Journal of International Education Studies Vol 5(3) Pp 4448

El-Omari, A. H. (2016) Factors affecting students' achievement in English language learning; Journal of educational and social Research; Vol 6(2) Pp 9-17 MCSER, Rome-Italy

List of All Educationally Less Developed States (ELDS) In Nigeria (2016) retrieved from https://www.bentenblog.com>others

Mohammed, A. A. (2013) The effect of teaching literature on learning English language: A study on EFS (English as a Foreign Students) and EFL Classes: International Journal of Sciences and Research (ijsr)Pp 27-38.

Murat, H. (2005) Teaching English through literature ; Journal of Language and Linguistic studies, (1) : Pp 53-66.

Musari, A. (2016) Much Ado About Educationally Less Developed States: The guardian Newspaper Nigeria 7 th Nov,2016; retrieved online fromhttps:/guardian.ng $>$ features on $22 / 3 / 18$.

Newhouse, D \& Beegle, K. (2005) The effect of school type on academic achievement: Evidence from Indonesia retrieved from on 22/3/18.

The University of Sheffield: Prospective International Students retrieved from https://www.sheffield.ac.uk > 
countries on $23 / 3 / 18$.

The University of Shefield: Entry requirements for students from Nigeria; retrieved from https://www.sheffield.ac.uk > countries on 23/3/18.

Yusuf, M. A. \& Adigun, J. T. (2010) The influence of school sex, location and type on students' academic performance International journal of Educational Science Vol 2(2) Pp 81-85.

Murat, H. (2005) Teaching English through literature Journal of language and linguistic studies Vol 1(1) Pp 5366.

Paran, A. (2017) The effectiveness of literature on acquisition of language skills and intercultural retrieved from www.ioe.ac.uk on $21 / 8 / 18$.

Oyetunde, T. O. (2013) The Intentional English Teacher: theories, methods\& activities; tips for teaching English functionally. LECAPS, Jos, Plateau State.

Adejimola, A. S. \& Ojuolape, M. A. (2013) Enhancing students' performance in the language through literature in English in the secondary schools; academicJournals Vol 8 (24) Pp 2241-2248 retrieved online from https://www.academicjournals.org/ERR on 21/3/18.

Profesorado, F. (2010) How literature can influence the English language learning? Retrieved from https://blogs.funiber.org/formacion-profesorado/2010/10/08/how-litrature-can-influe.

Doarne, B. T. (2008) the relationship between school facilities and academic achievement; unpublished M.Ed project of the faculty of the college of education, Ohio University.

Ugbe, A. U. \& Agim, J. I. (2009) influence of teachers' competence on students' academic performance in senior secondary school chemistry.Global Journal of Educational Research Vol 8 (1-2) retrieved from http://dx.doi.org/10.4314/gjedr.v8i1-2.53770 on 24/3/18.

Omotere,T. (2011) Effects of teachers' competence on students' academic performance : A case study of Ikeja local government area of Lagos state. Retrieved online from https://egoboosterbooks.wordpress.com>.

Agharuwhe, A. A. (2013) effects of teachers effectiveness on students' academic performance in public secondary schools; Delta state, Nigeria. Journal of educational and social research vol. 3 (3) Retrieved online from www.mcser.org on 24/3/18.

Prasetio, A. P. (2017) Lecturer's professional competency and students' academic performance in Indonesia. International Journal of Human ResourceStudies. Vol 7(1) Pp 86-93 Retrieved online from https://www.researchgate.net/publication/314484300 on 24/3/18.

Larsen-Freeman, D. M. \& Anderson, M. (2015) Techniques \& Principles in language teaching; Oxford University Press. 